\title{
Green Synthesis of Silver Nanoparticles Using Novel Launaea Procumbens Leaves Extract and Screening Its Antibacterial Activity
}

Sanjay Ratan Kumavat ( $\nabla$ srkumavat@rediffmail.com )

University Institute of Chemical Technology, KBCNMU,Jalgaon https://orcid.org/0000-0003-1595-1944

\section{SATYENDRA MISHRA}

University Institute of Chemical Technology, KBCNMU,Jalgaon

\section{Research Article}

Keywords: Silver nanoparticles, Launaea procumbens, Green synthesis, HR-TEM, Antibacterial activity

Posted Date: November 11th, 2021

DOI: https://doi.org/10.21203/rs.3.rs-1049725/v1

License: (c) (i) This work is licensed under a Creative Commons Attribution 4.0 International License.

Read Full License 


\section{Abstract}

Plants are emerging as a cost-effective and ecofriendly method for green synthesis of nanoparticles. The plant extract Launaea procumbens was used as a reduction agent in the green synthesis of silver nanoparticles. UV-Visible spectroscopy, HR-TEM, SAED, FE-SEM, EDAX, DLS, and FT-IR were used to study the green synthesized silver nanoparticles. UV-Vis spectroscopy of a prepared silver solution revealed maximum absorption at $435 \mathrm{~nm}$. The synthesized silver nanoparticles were found to be spherical in shape with a size in the range of 24.28 to $31.54 \mathrm{~nm}$. DLS analysis was used to determine the size of the green synthesized silver nanoparticles, which showed outstanding antibacterial action against Grampositive bacteria Bacillus subtilis and Staphylococcus aureus, as well as Gram-negative bacteria Escherichia coli and Pseudomonas aeruginosa. Gram-positive Bacillus subtilis had a maximum zone of inhibition of $20 \mathrm{~mm}$, Staphylococcus aureus had a zone of inhibition of $19 \mathrm{~mm}$, and Gram-negative bacteria Escherichia coli and Pseudomonas aeruginosa had zones of inhibition of $13 \mathrm{~mm}$.

\section{Introduction}

The latest advances in nanotechnology concentrate on methods of synthesis that are environmentally sustainable and cost-effective. Green nanoparticle synthesis is an environmentally friendly, easy approach and a healthy mode of nanomaterial synthesis, using natural tools. This eco-friendly approach has heralded a new era of equilibrium nanotechnology [1].

Natural methods use plants, bacteria, fungi, algae, etc. for the synthesis of nanoparticles. The plant extracts secret certain phytochemicals that act as a reducing and capping agent for silver nanoparticle (AgNPs) synthesis [2]. The ability of leaves, bark, stems, shoots, seeds, roots, twigs, peels, berries, seedlings, and tissue crops to synthesize nanoparticles has been confirmed [3]. The natural extract was used in the green synthesis of metal and metal oxide nanoparticles. Importantly, the role of biological components, such as flavonoids, steroids, proteins, Saponins, tannin, alkaloids, terpenoids, aldehydes, and phenolic compounds, as reducing agents and solvents was studied. Green synthesis manufacturing of nanoparticles minimises time and can obtain the desired size and shape to improve the stability of nanoparticles. Due to the quick, cost-effective, and environmentally friendly way of synthesizing nanoparticles through the biological system, the area of nanoparticle production is most assured at the present time $[4,5]$.

Green synthesis has recently gained popularity over other chemical and physical methods because it offers nanoparticles that are environmentally friendly, biocompatible, inexpensive, shape, and sizecontrolled. Various methods of synthesis, like ultra-sonication [6], continuous synthesis by microreactor [7], etc., including green approaches, are available in the literature. Due to their non-toxic, eco-friendly, and economical and biocompatible nature, routes based on the use of plants, fungi, and bacteria are essential. In addition, AgNPs prepared using the above methods also do not use toxic chemicals, which makes them suitable for use in medical and pharmaceutical applications [2, 3]. 
Several actual pieces of evidence indicate that silver ions play an important role in the antimicrobial activities of AgNPs. The surface area of the nanomaterial is a main characteristic of the antimicrobial toxicity of AgNPs. The largest concentration of liberated silver ions was reported in the case of AgNPs with the greatest surface area. Silver nanoparticles having the smallest surface area emit the fewest silver ions, resulting in poor antimicrobial activities $[8,9]$. The antimicrobial activities of AgNPs are mostly determined by the size, $\mathrm{pH}$, and ionic strength of the medium, as well as the type of capping agent used. However, the exact mechanism of AgNPs antibacterial or toxicological actions is still unknown and unsolved. Perhaps AgNPs release silver ions regularly, which could be one of the mechanisms underlying AgNP bactericidal activity [10]. The positively charged $\mathrm{Ag}^{+}$plays an important part in exhibiting the antibacterial or toxicity activities of silver, and the silver basically must be in its ionised state to retain its antibacterial or toxicity activities [11]. It has been discovered that $\mathrm{Ag}^{+}$ions form complexes with nucleic acids and, unlike phosphate groups, they selectively bind with the nucleosides of nucleic acids. As a result, all types of silver or silver-containing composites with antibacterial properties are eventually generators of $\mathrm{Ag}+$ ions $[12,13]$. Electrostatic attraction between negatively charged microbial cells and positively charged nanoparticles has been demonstrated in several studies, and these nanoparticulate systems have been recommended as the most effective bactericidal agents. Because of electrostatic attraction and affinity for sulfur proteins, Ag+ ions stick to the cytoplasm and cell wall, dramatically increasing permeability and causing bacterial casings to rupture [14-17]. Reports are available on the development of the green synthesis of nanoparticles using different plant extracts (Table 1).

The benefit of plant and leaf extracts involves the creation of stable nanoparticles, even though they are stored for a longer period. In the present study, we have synthesized AgNPs using leaves of Launaea procumbens, which is commonly known as Pathari. In general, Launaea procumbens was used as an ayurvedic herbal medicine prepared from this plant to facilitate good health, self-healing, and longevity, as well as being used as a food ingredient. The leaves of Launaea procumbens are used to treat fever, cancer, and swelling; a paste of the leaves has also been used to treat rheumatism, boils, and swelling. The plant has demonstrated insecticidal efficacy and is used for the treatment of rheumatism, reproductive disorders, inflammation, oxidative renal dysfunction, hormonal imbalances, and liver dysfunction $[18,19]$. The antibacterial activity of Launaea procumbens leaf extract was confirmed by the absence of a zone of inhibition in E. coli, P. aeruginose, P. mirabilis, Acetobacter spp., as well as K. pneumoniae [20]. Thus, we clarified the synthesis of AgNPs using Launaea procumbens leaves without the addition of any external surfactant and capping agent. We have therefore tried an easy, non-toxic, ecofriendly, and economically viable green synthesis method of AgNPs, which has remained stable in liquid form for one month.

Table 1 Different plant materials used for the green synthesis of nanoparticles its size range and shape. 


\begin{tabular}{|c|c|c|c|c|c|}
\hline $\begin{array}{l}\text { S. } \\
\text { no. }\end{array}$ & $\begin{array}{l}\text { Plant materials } \\
\text { (Family) }\end{array}$ & $\begin{array}{l}\text { Metal } \\
\text { nanoparticles }\end{array}$ & Size & Shape & References \\
\hline 1 & $\begin{array}{l}\text { Vitex negundo } \\
\text { (Lamiaceae) }\end{array}$ & $\mathrm{Ag}$ & $5-47 \mathrm{~nm}$ & Spherical & [21] \\
\hline 2 & $\begin{array}{l}\text { Hibiscus rosa-sinensis } \\
\text { (Malvaceae) }\end{array}$ & $\mathrm{Ag}$ & $13 \mathrm{~nm}$ & Spherical & [22] \\
\hline 3 & $\begin{array}{l}\text { Coriandrum sativum } \\
\text { (Apiaceae) }\end{array}$ & $\mathrm{Ag}$ & $8-75 \mathrm{~nm}$ & Spherical & [23] \\
\hline 4 & $\begin{array}{l}\text { Punica granatum seeds } \\
\text { (Punicaceae) }\end{array}$ & $\mathrm{Ag}$ & $\begin{array}{l}10-35 \\
n m\end{array}$ & Spherical & [24] \\
\hline 5 & $\begin{array}{l}\text { Coccinia grandis } \\
\text { (Cucurbitaceae) }\end{array}$ & $\mathrm{Ag}$ & $\begin{array}{l}20-30 \\
\mathrm{~nm}\end{array}$ & Spherical & [25] \\
\hline 6 & $\begin{array}{l}\text { Ocimum tenuiflorum } \\
\text { (Lamiaceae) }\end{array}$ & $\mathrm{Ag}$ & $\begin{array}{l}25-40 \\
\mathrm{~nm}\end{array}$ & Spherical & [26] \\
\hline 7 & $\begin{array}{l}\text { Coleus aromaticus } \\
\text { (Lamiaceae) }\end{array}$ & $\mathrm{Ag}$ & $44 \mathrm{~nm}$ & Spherical & [27] \\
\hline 8 & $\begin{array}{l}\text { Tamarindus indica } \\
\text { (Fabaceae) }\end{array}$ & $\mathrm{Ag}$ & $6-8 \mathrm{~nm}$ & Spherical & [28] \\
\hline 9 & $\begin{array}{l}\text { Alstonia } \\
\text { scholaris (Apocynaceae) }\end{array}$ & $\mathrm{Ag}$ & $\begin{array}{l}15-38 \\
n m\end{array}$ & Spherical & [29] \\
\hline 10 & Uraria picta (Fabaceae) & $\mathrm{Ag}$ & $\begin{array}{l}12.54 \text { to } \\
25.58 \\
\mathrm{~nm}\end{array}$ & Spherical and Oval & [30] \\
\hline 11 & $\begin{array}{l}\text { Borogo Officinalis } \\
\text { (Boraginaceae) }\end{array}$ & $\mathrm{Ag}$ & $22 \mathrm{~nm}$ & Spherical & [31] \\
\hline 12 & $\begin{array}{l}\text { Cinnamomum } \\
\text { camphora (Lauraceae) }\end{array}$ & $A g \& A u$ & $\begin{array}{l}55-80 \\
\mathrm{~nm}\end{array}$ & Triangular, spherical & [32] \\
\hline 13 & $\begin{array}{l}\text { Coriandrum sativum } \\
\text { (Apiaceae) }\end{array}$ & $\mathrm{Au}$ & $\begin{array}{l}6.75- \\
57.91 \\
\mathrm{~nm}\end{array}$ & $\begin{array}{l}\text { Spherical, triangle, } \\
\text { truncated triangles and } \\
\text { decahedral }\end{array}$ & [33] \\
\hline 14 & $\begin{array}{l}\text { Lantana camara Linn } \\
\text { (Verbenaceae) }\end{array}$ & $\mathrm{Au}$ & $6-7 \mathrm{~nm}$ & Spherical & [34] \\
\hline 15 & $\begin{array}{l}\text { Cinnamomum } \\
\text { zeylanicum (Lauraceae) }\end{array}$ & $\mathrm{Au}$ & $25 \mathrm{~nm}$ & Prism, Spherical & [35] \\
\hline 16 & $\begin{array}{l}\text { Garcinia mangostana } \\
\text { (Guttiferae) }\end{array}$ & $\mathrm{Au}$ & $\begin{array}{l}32.96 \pm \\
5.25 \mathrm{~nm}\end{array}$ & $\begin{array}{l}\text { Spherical, hexagonal } \\
\text { and triangular }\end{array}$ & [36] \\
\hline
\end{tabular}




\begin{tabular}{|clllll|}
17 & $\begin{array}{l}\text { Citrus maxima peels } \\
\text { (Rutaceae) }\end{array}$ & Fe & $\begin{array}{l}10-100 \\
\mathrm{~nm}\end{array}$ & Irregular & [37] \\
\hline 18 & $\begin{array}{l}\text { Eucalyptus robusta } \\
\text { (Myrtaceae) }\end{array}$ & Fe & $2.0 \mathrm{~nm}$ & Spherical & [38] \\
\hline 19 & $\begin{array}{l}\text { Erodium cicutarium } \\
\text { (Geraniaceae) }\end{array}$ & Ag \& Fe & $\begin{array}{l}21.4, \\
32.2 \mathrm{~nm}\end{array}$ & Spherical & [39] \\
\hline 20 & $\begin{array}{l}\text { Stigmaphyllon ovatum } \\
\text { (Malpighiaceae) }\end{array}$ & $\begin{array}{l}\text { Ag, Au \& Ag- } \\
\text { Au }\end{array}$ & $\begin{array}{l}23.5,78, \\
14.9 \mathrm{~nm}\end{array}$ & Triangular & [40] \\
\hline
\end{tabular}

\section{Materials And Methods}

\subsection{Chemicals and Plant collection}

Extra pure silver nitrate (99.99\%) was purchased from Loba Chemie Pvt Ltd, and de-ionized water was used for the experiments. Fresh mature plants with Launaea procumbens (family-Asteraceae) leaves were collected from the Kavayitri Bahinabai Chaudhari North Maharashtra University Campus, Jalgaon, Maharashtra, India. The plant material was identified with the help of an expert taxonomist.

\subsection{Preparation of leaves extract}

The leaves from the plants were separated, washed under running tap water, further washed four times with de-ionized water to remove dust particles, shade dried for eight to ten days in the air, and then the dried leaves were crushed into a powder using the electronic blender and stored in a separate airtight container at room temperature for further use.

$10 \mathrm{gm}$ of the fine powder of Launaea procumbens leaves was added to $100 \mathrm{ml}$ of deionized water and stirred at $80-90^{\circ} \mathrm{C}$ for $60 \mathrm{~min}$. The leaf extract was allowed to cool at room temperature before being filtered through Whatman No.1 filter paper. Further, the filtered extract was cooled to room temperature, and the formation of a yellow-greenish colour left the broth and it was stored for future use. This extract was used as a reduction agent as well as a stabilizing agent.

\subsection{Phytochemical screening}

The extract solution was screened for phytochemicals such as alkaloids, flavonoids, steroids, proteins, saponins, tannin, terpenoids, and phenolic compounds using standard procedures $[55,56]$

\subsection{Synthesis of silver nanoparticles}

As a precursor for the synthesis of silver nanoparticles, silver nitrate $\left(\mathrm{AgNO}_{3}\right)$ was used. $70 \mathrm{ml}$ of $1 \mathrm{mM}$ silver nitrate aqueous solution with $30 \mathrm{ml}$ of leave extract was taken in a conical flask and put on the 
magnetic stirrer for $30 \mathrm{~min}$ at $60-70{ }^{\circ} \mathrm{C}$ until the colour change was observed. The reduction of $\mathrm{Ag}^{+}$ions to $\mathrm{Ag}^{0}$ was supported by a shift in the colour of the solution from a yellow-greenish to a brownish color, suggesting the formation of AgNPs.

\subsection{Characterization of nanoparticles}

200 to $800 \mathrm{~nm}$ at a resolution of $1.5 \mathrm{~nm}$ (Agilent Cary 60 Spectrophotometer The synthesized green silver nanoparticles were characterized by UV-vis spectroscopy to observe the reduction of silver nanoparticles by the action of the leave extract. The biologically reduced brownish colour solution mixture was scanned by UV-absorption spectra in the wavelength range from). In this analysis, the leaves extracted without adding silver nitrate $\left(\mathrm{AgNO}_{3}\right)$ were used as a control.

The FTIR spectra were recorded on the extract, which was exposed before and after the addition of the silver nitrate solution. The FTIR spectra were scanned using the Perkin Elmer Fourier transform infrared spectrophotometer, at a resolution of $4 \mathrm{~cm}^{-1}$ in the range of $450-4000 \mathrm{~cm}^{-1}$.

Dynamic light scattering (DLS) of the silver nanoparticles was done on the Malvern Zetasizer Instrument to obtain particle sizes and size distributions.

The morphology of the prepared products was observed by Field Emission Scanning Electron Microscopy (FESEM) and Energy Dispersive X-ray Spectroscopy (EDXS) using the model S-4800 Type II Hitachi High Technology Corporation Limited, JAPAN, operated at $15.0 \mathrm{keV}$.

Silver nanoparticles (AgNPs) size, shape, and morphology were studied by High-resolution transmission electron microscopy (HR-TEM). High-resolution transmission electron microscopy (Jeol/JEM 2100). This instrument operates at a $200 \mathrm{kV}$ accelerating voltage. In addition, the elemental projection of a selected area of on electron diffraction pattern (SAED) was done. The HR-TEM sample was prepared by putting a drop of the colloid silver nanoparticles on a copper grid coated with carbon and then drying it at room temperature before moving it to the microscope.

\subsection{Screening of antibacterial activity}

The present investigation, the antibacterial effect of prepared silver nanoparticles was studied on different types of bacteria such as Bacillus subtilis, Pseudomonas aeruginosa (Gram-positive), and Escherichia coli, Staphylococcus aureus (Gram-negative). Bacterial suspensions were prepared and $100 \mu \mathrm{l}$ of suspension was placed on the agar plate with sterile nutrients. Using a cork-borer, two wells were prepared on each plate of nutrients. The $100 \mu \mathrm{l}$ of given silver nanoparticles were inoculated in one well and $100 \mu \mathrm{l}$ of distilled water was inoculated in each well. All plates were kept at $4^{\circ} \mathrm{C}$ and then incubated at $37^{\circ} \mathrm{C}$ for diffusion. The used distilled water served as control. After the incubation period, the zones of inhibition were observed and tabulated.

\section{Results And Discussion}




\subsection{UV-Visible absorption spectroscopy}

It is well known that silver nanoparticles exhibit a yellow-greenish color in aqueous solution because the UV-visible spectrum excitation depends on the particle size $[41,42]$. The synthesized silver nanoparticles were confirmed by color formation from a yellow-greenish to a brownish color due to the reduction of silver salt by the presence of reducing agents in the aqueous extract of Launaea procumbens. The UVvisible absorption spectrum of the synthesized silver nanoparticles was obtained at $435 \mathrm{~nm}$ (Fig. 1). The broadening of the peak refers to polydispersed silver nanoparticles in the solution. Silver nanoparticles exhibit unique and tunable optical properties on account of their surface plasmon resonance depending on the shape and size distribution of the nanoparticles.

\subsection{Fourier Transform Infrared Spectroscopy}

FTIR spectra were conducted to classify potential functional classes of the leave biomolecules of Launaea procumbens extract which is responsible for the reduction of silver ions to silver nanoparticles. The phytochemicals analysis of Launaea procumbens reveals the presence of alkaloids, flavonoids, steroids, Saponins, and Phenolic compounds [20,43-44]. The key functional groups that were present in the leaves of Launaea procumbens and synthesized nanoparticles were identified by an analysis of infrared content. The FTIR spectra of the aqueous extract revealed a broad and strong peak at $3314 \mathrm{~cm}^{-1}$, which could be attributed to the $\mathrm{OH}$ starching vibrations of secondary metabolites such as alkaloids, flavonoids, steroids, Saponins, and other Phenolic compounds [20,44]. This functional group has been modified in to synthesized nanoparticles made of silver. Because of the $\mathrm{O}-\mathrm{H}$ stretching vibrations and $\mathrm{H}-$ bonded alcohol and phenol groups, the wide and strong absorption band was observed at $3381 \mathrm{~cm}^{-}$ ${ }^{1}$ (Fig. 2b). The strong absorption peak at $2972 \mathrm{~cm}^{-1}$ got shifted to $2927 \mathrm{~cm}^{-1}$ assigned to the $\mathrm{C}-\mathrm{H}$ stretching of aromatic compound. A weak band was observed at $1623 \mathrm{~cm}^{-1}$ which corresponds to the $1587 \mathrm{~cm}^{-1}$ thatcould be assigned to carbonyl starching in the carboxyl group ( $\mathrm{N}-\mathrm{H}$ band) of linking proteins present in the leaves $[45,46]$. This study shows different stretches of bonds shown at different peaks; 1377,1225 , and $1040 \mathrm{~cm}^{-1}$ (Fig. 2a) can be assigned to the $\mathrm{O}-\mathrm{H}$ bonds and $\mathrm{C}-\mathrm{O}$ stretching vibrations band observed. The absorption peaks at $1450 \mathrm{~cm}^{-1}$ could be attributed to the presence of $\mathrm{C}-\mathrm{H}$ bending. The intense weak band at 1118 and $1033 \mathrm{~cm}^{-1}$ (Fig. 2 b) can be assigned to the C-O and C-N stretching vibrations of aliphatic amines [46, 47]. The FTIR study shows that the groups of the leaves of Launaea procumbens extract hydroxyl, carboxyl, and amine are primarily involved in reducing $\mathrm{Ag}^{+}$to $\mathrm{Ag}^{0}$ nanoparticles.

\subsection{Size Distribution Analysis of Silver Nanoparticles by DLS}

Green synthesized silver nanoparticles were analyzed for particle size distribution and the results showed that they were distributed in to different sizes in a polydispersible mode. The particle size in a colloidal solution was measured using DLS. The size of the particles was found to be 223 and $73 \mathrm{~nm}$ with diameters of 57.07 and $18.14 \mathrm{~nm}$ at the first and second peaks, and the peak strength was found to be $88.3 \%$ and $11.7 \%$, respectively. The mean average silver nanoparticles were $378.4 \mathrm{~nm}$ in size. It was 
found that the Polydispersity index was 0.645 (Fig. 3). The ratio of particles of different sizes to the total number of particles is measured by the Polydispersity index. The results obtained from the size distribution from DLS analysis show the larger size of the particles, which is due to the aggregation of the silver nanoparticles $[48,49]$.

\subsection{Field Emission Scanning Electron Microscopy (FE-SEM) and Energy Dispersive X-ray Spectroscopy (EDXS)}

The synthesized silver nanoparticles were characterized by standard characterization methods such as field emission scanning electron microscopy. To examine the morphology, structure, scale, shape, and distribution of the nanoparticles produced, a field emission scanning electron microscope was used. The FE-SEM is better and more resolute than the traditional SEM [50]. The synthesized nanoparticles appear larger due to aggregation. Most of the nanoparticles were aggregated, polydispersed, and cluster shaped (Fig.4). The energy dispersive spectrum of the synthesized nanoparticles indicates the presence of silver as an ingredient element. Metallic silver nanoparticles generally show a typically strong signal of the peak at $3 \mathrm{KeV}$, which is typical for absorption of metallic silver nanoparticles [51,52]. Figure 5 shows the quantitative information of synthesized silver nanoparticles. The presence of elements such as Ag, $0, C$, $\mathrm{Cl}, \mathrm{Na}$, and $\mathrm{Ca}$ is shown in Fig. 5.

\subsection{High Resolution Transmission Electron Microscopy (HR-TEM) with SAED Analysis}

We have carried out a high-resolution transmission electron microscopic (HRTEM) study to obtain information about the internal structure (size and morphology) of the green synthesized silver nanoparticles as shown in Fig. 6. The HR-TEM images were recorded at different magnifications to find the individual particles. The synthesized silver nanoparticles were observed as almost spherical in shape and nearly monodispersed in nature and the average size of the particles was 24.28 to $31.54 \mathrm{~nm}$. The distance between the lattice fringe spacing of silver nanoparticles (AgNPs) was recorded as $0.23 \mathrm{~nm}$ (Fig. $6 e)$ and the selected area diffraction pattern of the silver nanoparticles suggested that face-centered cubic (fcc) crystalline silver was presented by the synthesized silver nanoparticles (Fig. 6f) [50, 53-54].

\subsection{Phytochemical composition of Launaea procumbens}

Phytochemical analysis findings revealed the presence of alkaloids, flavonoids, steroids, proteins, saponins, tannin, phenolic compounds and the absence of terpenoids as shown in Table 2. Significant bioactive components in phytochemicals serve as reducers for reactions. Silver ions and thus extracts have been used as a reduction and stabilization agent in the green synthesis of silver nanoparticles [55, 56].

Table 2 Phytochemicals screening of Launaea procumbens leaves extract. 


\begin{tabular}{|ll|}
\hline Phytochemicals & Results \\
\hline Alkaloids & ++ \\
\hline Flavonoids & ++ \\
\hline Steroids & ++ \\
\hline Terpenoids & - \\
\hline Proteins & ++ \\
\hline Saponins & ++ \\
\hline Tannin & ++ \\
\hline Phenolic Compounds & $\mathbf{+ +}$ \\
\hline
\end{tabular}

$++=$ Presence,$+=$ Trace, $-=$ Absence

\subsection{Antibacterial activity of silver nanoparticles}

The agar well diffusion method was employed for the determination of the antibacterial activity of silver nanoparticles. Four different suspension cultures of Bacillus subtilis, Staphylococcus aureus, Escherichia coli, and pseudomonas aeruginosa were spread on nutrient agar medium by the spread plate technique. The plates were incubated at $37 \otimes C$ for 24 hours. $0.1 \mathrm{ml}$ of silver nanoparticles were inoculated in to one well and $0.1 \mathrm{ml}$ of distilled water was inoculated in to another well on each plate and water served as a control $[45,55]$. Antibacterial tests of synthesized silver nanoparticles and Launaea procumbens leaves extract were investigated using a disc diffusion method carried out against four bacteria. The green synthesized silver nanoparticles showed excellent antibacterial activity against Gram-positive bacteria Bacillus subtilis, Staphylococcus aureus, and gram-negative bacteria Escherichia coli, Pseudomonas aeruginosa. The Gram-positive bacterium Bacillus subtilis showed a maximum zone of inhibition of 20 $\mathrm{mm}$. Staphylococcus aureus showed a zone of inhibition of $19 \mathrm{~mm}$. The gram-negative bacteria Escherichia coli andPseudomonas aeruginosa bacteria showed a zone of inhibition of $13 \mathrm{~mm}$. The mean inhibitory zone of the four replicates of diameter was measured and tabulated in Table 3.

Borago officinalis leaf extract was discovered to be beneficial in the green synthesis of silver nanoparticles. The synthesized AgNPs showed antimicrobial activity against $E$. coli bacteria with an inhibition zone of $8 \mathrm{~mm}$ and no inhibition zone against other bacteria such as S. Typhi, B. subtilis, and $S$. aureus, and only $C$. albicans inhibits the inhibition zone of $6 \mathrm{~mm}$ while $A$. flavus is not inhibited in the absence of activity [31].

Because of the antibacterial activities of the plant extract, as well as the nanoparticles high aspect ratio and penetration potential, an additional effect of related phytochemicals by deposition on silver nanoparticles could produce greater antibacterial effects. On the other hand, one of the fundamental mechanisms underlying silver nanoparticles antibacterial activity is the generation of reactive oxygen 
species (ROS) [57]. The most important aspects of antimicrobial activity discussed were silver ion release, cell membrane damage, DNA interactions, free radical generation, bacterial resistance, and the difference between resistance to silver ions and resistance to silver nanoparticles [58]. The antibacterial activity of silver nanoparticles against $S$. aureus and $E$. coli cells was significant. The growth and reproduction of bacterial cells treated with silver nanoparticles was rapidly inhibited. The growth of silver nanoparticles treated cells was unchanged by $\mathrm{pH}$ or temperature changes. Silver nanoparticles were found to actively form bactericidal reactive oxygen species (ROS) [58]. Krishnaraj et al. 2010 [59] produced silver nanoparticles from Acalypha indica leaf extract, and $10 \mu \mathrm{g} / \mathrm{ml}$ was determined to be the minimum inhibitory concentration (MIC) against E. coli and $V$. Cholera. This was explained by the alteration in membrane permeability, which caused the antibacterial activity. Some reports indicated improved antibacterial efficacy, which was most likely due to the reduced size of the AgNPs. For example, using an average mean size of $16 \mathrm{~nm}$ and anti bactericidal property at $45 \mu \mathrm{g} / \mathrm{mL}$ on E. coli. Several potential methods for how AgNPs work as antibacterial agents have been postulated, but the specific mechanism is unknown [60]. The antibacterial activity of synthesized silver nanoparticles compared to that of saffron extract and purchased silver nanoparticles against six pathogenic bacteria revealed that the aqueous extract of saffron and purchased nanoparticles had no significant antibacterial effect, but biosynthetic nanoparticles were able to inhibit the total bacteria studied [61]. Espanti et al. 2016 [62] investigated the antimicrobial properties of synthesized silver nanoparticles by Terminal chebula Retz (Myrobalan) against E. coli and Bacillus subtilis in a study performed, and the results showed that silver nanoparticles have a much stronger antibacterial effect than the plant's aqueous extract. Silver nanoparticles kill bacteria by destroying their membranes.

Table 3 Antibacterial activity of green synthesized silver nanoparticles using Launaea procumbens leaves extract.

\begin{tabular}{llll}
\multirow{2}{*}{\begin{tabular}{l} 
Organisms \\
\cline { 3 - 4 }
\end{tabular}} & \multicolumn{2}{l}{$\begin{array}{l}\text { Zone of inhibition }(\mathrm{mm}) \\
\text { Synthesis of AgNPs }(100 \mu \mathrm{l})\end{array}$} & $\begin{array}{l}(\text { Control }) \text { Deionized } \mathrm{H}_{2} \mathrm{O} \\
(100 \mu \mathrm{l})\end{array}$ \\
\hline 1. & Bacillus subtilis & 20 & $\mathrm{NZ}$ \\
\hline 2. & Pseudomonas aeruginosa & 19 & $\mathrm{NZ}$ \\
\hline 3. & Staphylococcus aureus & 13 & $\mathrm{NZ}$ \\
\hline 4. & Escherichia coli & 13 & $\mathrm{NZ}$
\end{tabular}

(NZ: no zone of inhibition)

\section{Conclusion}

In summary, silver nanoparticles were green synthesized by the Launaea procumbens leave extract without the addition of any toxic reducers or stabilizers. HR-TEM studies revealed that the spherical 
shape of nanoparticles is in the range of 24.28 to $31.54 \mathrm{~nm}$. Most of silver nanoparticles are aggregated, polydispersed, and cluster-shaped, according to FE-SEM images. The energy dispersive spectrum of the synthesized nanoparticles shows the presence of silver as an ingredient element. The silver nanoparticles synthesized from the leaves of Launaea procumbens demonstrated excellent antibacterial activity against Gram-positive bacteria; Bacillus subtilis demonstrated a maximum zone of inhibition of $20 \mathrm{~mm}$, Staphylococcus aureus demonstrated a zone of inhibition of $19 \mathrm{~mm}$, and Gram-negative bacteria Escherichia coli and Pseudomonas aeruginosa both demonstrated a zone of inhibition of $13 \mathrm{~mm}$. Furthermore, green synthesis of silver nanoparticles using plant materials is the most conventional and ecofriendly approach as compared to chemical and physical synthesis. The current study shows a simple, first-time synthesis of Launaea procumbens plant extract as well as an efficient approach to the synthesis of silver nanoparticles.

\section{Declarations}

\section{Acknowledgements}

The Authors thank Prof. B. L. Chaudhari, School of Life Sciences, KBCNMU, Jalgaon, for providing the antibacterial samples. SK is thankful to STIC Cochin for the HR-TEM Analysis.

\section{Funding}

None.

Conflict of interest The author has no conflict of interest to declare.

Ethical Approval Ethical rules are followed.

\section{ORCID}

Sanjay Kumavat

http://orcid.org/0000-0003-1595-1944

Satyendra Mishra

http://orcid.org/0000-0002-4789-8116

\section{References}

1. E. R. Balasooriya, C. D. Jayasinghe, U. A. Jayawardena et al. J Nanomater. 3, 1-10, 5919836, (2017). https://doi.org/10.1155/2017/5919836.

2. V. Kumar, \& SK. Yadav. J Chem Technol Biotechnol. 84 (2) 51-157, (2009). 
3. A. Sharma, S. Thomas, AM. Mathew and AK. Agarwal. Mapana J Sci 18 (2), 37-44, 0975-3303, (2019).

4. KB. Narayanan, \& H H. Park. Eur J Plant Pathol. 140 (2), 185- 192, (2014).

5. D. Chugh, VS. Viswamalya \& B. Das. J Genet Eng Biotechnol. 19, 126, (2021). https://doi.org/10.1186/s43141-021-00228-w.

6. S. Mishra, N. G. Shimpi \& T, Sen T. J Polym Res 20 (1), 49, 1022-9760, 1572- 8935, (2013).

7. G. A. Patil, M. L. Bari, B. A. Bhanvase, V. Ganvir, S. Mishra, \& SH. Sonawane. Chem Eng Process Process Intensif. 62, 69-77, 0255- 2701, (2012).

8. E. Navarro, F. Piccapietra, B. Wagner, F. Marconi, R. Kaegi, N. Odzak, et al. En-viron Sci Technol. 42 (23), 8959-64, (2008).

9. K. Zawadzka , K. Kadziola , A. Felczak , N. Wronska, I. Piwonski, A. Kisielewska, et al. J Chem. 38, 3275-81, (2014).

10. RA. Bapat, TV. Chaubal, CP. Joshi et al. Mater Sci Eng C. 91, 881-898, (2018).

11. U. Klueh, V. Wagner, S. Kelly, A. Johnson, JD. Bryers. J Biomed Mater Res Part B: Appl Biomater. 53, 621-631, (2000).

12. Y. Yakabe, T. Sano, H. Ushio, T. Yasunaga. Chem Lett 9, 4, 373-376, (1980). https://doi.org/10.1246/cl.1980.373.

13. S. Chouhan, S. Guleria. Mater Sci Energy Technol. 3, 536-544, (2020).

14. YW. Cao, R. Jin, CA. Mirkin. J Am Chem Soc. 123, 7961-7962, (2001).

15. JB. Wright, K. Lam, D. Hanson, RE. Burrell. Am J Infect Control. 27, 344-350, (1999).

16. ED. Matthew, NM. Schaeublin, KE. Farrington, SH. Hussain, GR. Johnson. ACS Nano 3, 984-994, (2009).

17. S. Khorrami, A. Zarrabi, M. Khaleghi, M. Danaei, M. Mozafari. Int J Nanomed. 13, 8013-8024, (2018).

18. MC. Rathod, and DA. Dhale. Int J Pharm Res Scholars. 3 (1), 41-50, (2014).

19. P. Rawat, LM. Saroj, A. Kumar, TD. Singh, SK. Tewari, M. Pal. Phcog Mag. 12, S4:431-435, (2016).

20. G. J. Mishra and M. N. Reddy. Int. J Phytopharmacol. 3 (2), 147-151, (2012).

21. D. Prabhu, C. Arulvasu, G. Babu, R. Manikandan, P. Srinivasan. Process Biochem. 48 (2), 317-324, (2013).

22. D. Philip. Phys E. 42 (5) 1417-1424, (2010).

23. R. Sathyavathi, MB. Krishna, SV. Rao, R. Saritha, DN. Rao. Adv Sci Lett. 3 (2), 138-143, (2010).

24. K. Muthu, S. Rajeswari, B. Akilandaeaswari, SM. Nagasundari \& R. Rangasamy. Mater Technol. 1-10, (2020). https://doi:10.1080/10667857.2020.1786786.

25. R. Arunachalam, S. Dhanasingh, B. Kalimuthu, M. Uthirappan, C. Rose, AB. Mandal. Colloids Surf B94, 226-230, (2012).

26. RS. Patil, MR. Kokate, \& S. S. Kolekar. Spectrochim Acta A: Mol Biomol Spectrosc. 91, 234-238, (2012). 
27. M. Vanaja, G. Annadurai. Appl Nanosci. 3, 217-223, (2013). https://doi.org/10.1007/s13204-0120121-9

28. N. Jayaprakash, J J. Vijaya, K. Kaviyarasu, et al. J Photochem Photobiol. B 169, 178-185, (2017).

29. N. Shimpi, S. Shirole, \& S. Mishra. Micro Nanosyst. 7 (1), 49- 54, (2015).

30. S. Mishra, S. Kumavat. Micro Nanosyst. (2021). https://doi.org/10.2174/1876402913666210902161849.

31. S. R. Kumavat \& S. Mishra. Int Nano Lett. 11, 355-370, (2021). https://doi.org/10.1007/s40089-02100345-x.

32. J. Huang, Q. Li, D. Sun, et al. Nanotechnology 18, 105104-105115, (2017).

33. K B. Narayanan \& N. Sakthivel. Mater Lett. 62 (30), 4588-4590, (2008).

34. S S. Dash, B G. Bag, \& P. Hota. Appl Nanosci. 5 (3), 343-350, (2014).

35. S L. Smitha, D. Philip \& K G. Gopchandran. Spectrochim Acta A: Mol Biomol Spectrosc. 74 (3), $735-$ 739, (2009).

36. K. Xin Lee, K. Shameli, M. Miyake, et al. J Nanomater. 2,1-7, (2016).

37. Y. Wei, Z. Fang, L. Zheng, et al. Mater Lett. 185, 384-386, (2016).

38. Y. Vitta, M. Figueroa, M. Calderon, \& C. Ciangherotti. Mater Sci Energy Technol. 3, 97-103, (2020).

39. N. Maghsoudy, P A. Azar, M S. Tehrani, S W. Husain \& K. Larijani. J Nanostruct Chem. 9, 203-216, (2019).

40. E E. Elemike, DC. Onwudiwe, N. Nundkumar, M. Singh \& O. lyekowa. Mater Lett. 243, 148-152, (2019).

41. Rucha Desai, Venu Mankad, Sanjeev K. Gupta, and Prafulla K. Jha. Nanosci Nanotechnol Lett. 4, 3034, (2012).

42. E. Tomaszewska, K. Soliwoda, K. Kadziola, et al. J Nanomater. 60, 1-10, (2013).

43. A R. Vilchis-Nestor, V. Sanchez- Mendieta, M A. Camacho-Lopez, et al. Mater Lett. 62, 17-18: 31033105, (2008).

44. PR Meena Hemlata, AP Singh, and KK Tejavath. ACS Omega. 5 (10), 5520-5528, (2020).

45. V. Gopinath, D. Mubarak Ali, S. Priyadarshini, et al. Colloids Surf B 96,69-74, (2012).

46. C S T. Araujo, E I. Melo, V N. Alves \& N M M. Coelho. J Braz Chem Soc. 21 (9), 1727-1732, (2010).

47. K. Anandalakshmi, J. Venugobal, \& V. Ramasamy. Appl Nanosci. 6 (3) 399-408, (2015).

48. R.Yuvarajan, D. Natarajan, C. Ragavendran, \& R. Jayavel. J Photochem Photobiol B 149, 300-307, (2015). https://doi:10.1016/j.jphotobiol.2015.04.032.

49. [49] H. Erjaee, H. Rajaian, \& S. Nazifi. Nanotechnol. 8 (2) 025004, (2017).

50. L. Wang, H. Xu, L. Gu, et al. Mater Technol. 31 (8) 437-442,(2016). https://doi: 10.1080/10667857.2015.1105575.

51. K. Velayutham, \& R. Ramanibai. J Basic Appl Zool. 74, 16-22, (2016). https://doi.org/10.1016/j.jobaz.2016.02.002. 
52. J. Das, M. Paul Das \& P. Velusamy. Spectrochim Acta A: Mol Biomol Spectrosc. 104, 265-270, (2013).

53. M. Jha, NG. Shimpi. J Genet Eng Biotechnol. 16, 115-124, (2018). https://doi.org/10.1016/j.jgeb.2017.12.001.

54. E. Parthiban, N. Manivannan, R. Ramanibai, N. Mathivanan. Biotechnol Rep 21, e00297, (2018).https://doi.org/10.1016/j.btre.2018.e00297.

55. H. Padalia, P. Moteriya, S. Chanda. Arab J Chem 8, 5, 732-741, (2014).

56. M. Mondal, Md Solayman. Hossain, Nittananda Das, Abul Bashar Ripon. Khalipha, Arghya Prosun Sarkar, Md Tarikul Islam, Shanita Zaman Smrity, Sajal Biswas, , Sukalyan Kumar Kundu. Clinical Phytoscience. 5 (1), 8, (2019) https://doi.org/10.1186/s40816-019-0100-8.

57. V. Alt, T. Bechert, P. Steinrucke, et al. Biomater. 25, 4383-4391, (2004).

58. HS. Kim, HS. Lee, DS. Ryu, SJ. Choi, DS. Lee. J Microbiol Biotechnol. 39, 77-85, (2011).

59. C. Krishnaraj, EG. Jagan, S. Rajasekar, P. Selvakumar, PT. Kalaichelvan, N. Mohan. Colloids Surf B: Biointer. 76, 50-56, (2010).

60. A. Saxena, RM. Tripathi, F. Zafar, and P. Singh. Mater Lett. 67 (1) 91-94, (2012).

61. G. Bagherzade, MM. Tavakoli, MH. Namaei. Asian Pac J Trop Biomed. 7, 227-233, (2017).

62. CS. Espenti, KK. Rao, KM. Rao. Mater. Lett. 174, 129-133, (2016).

\section{Figures}




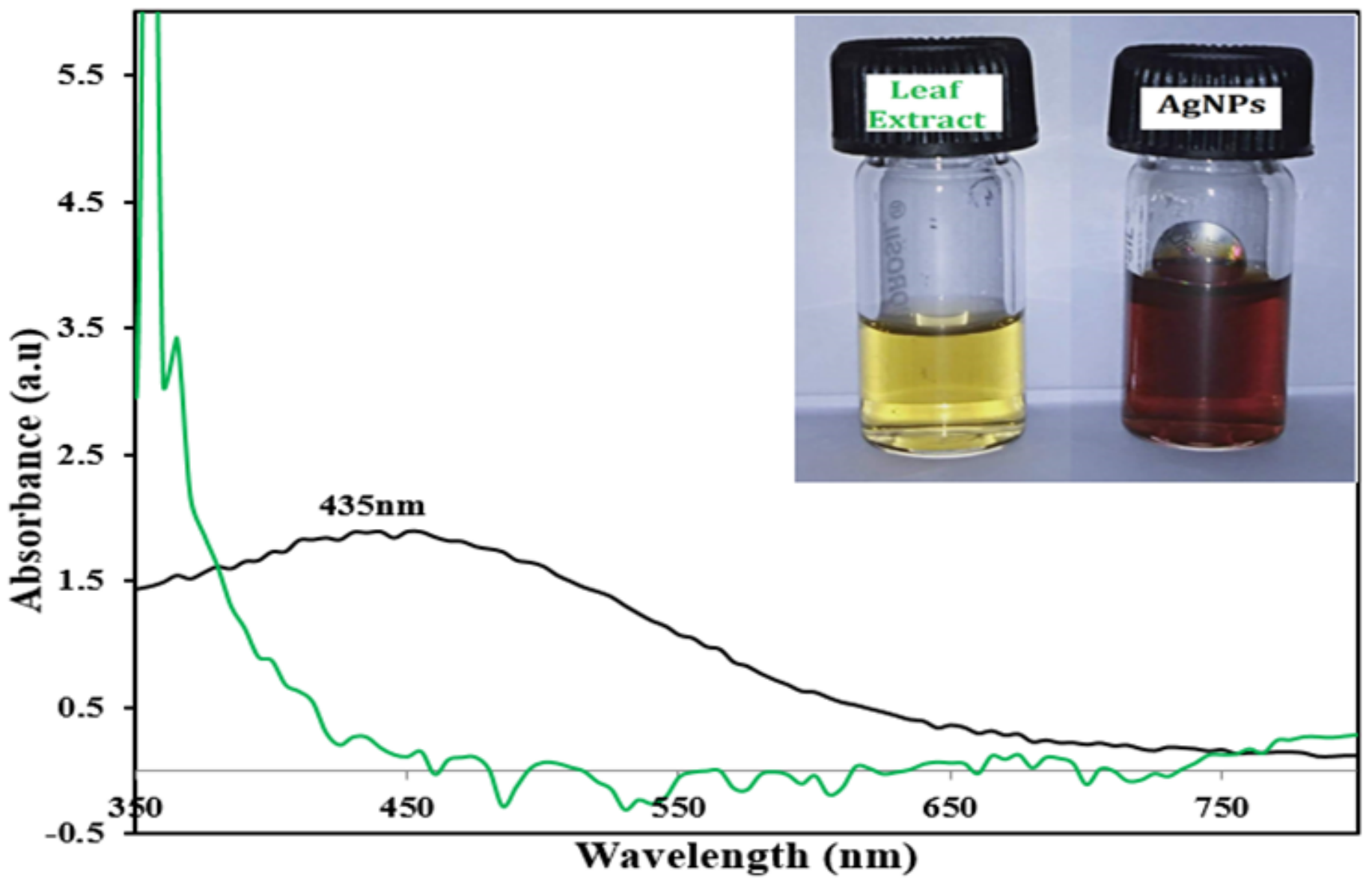

Figure 1

UV-visible absorption spectra of AgNPs synthesized by Launaea procumbens leaves extract. The figure inset shows the leaves extract and the synthesized AgNPs. 


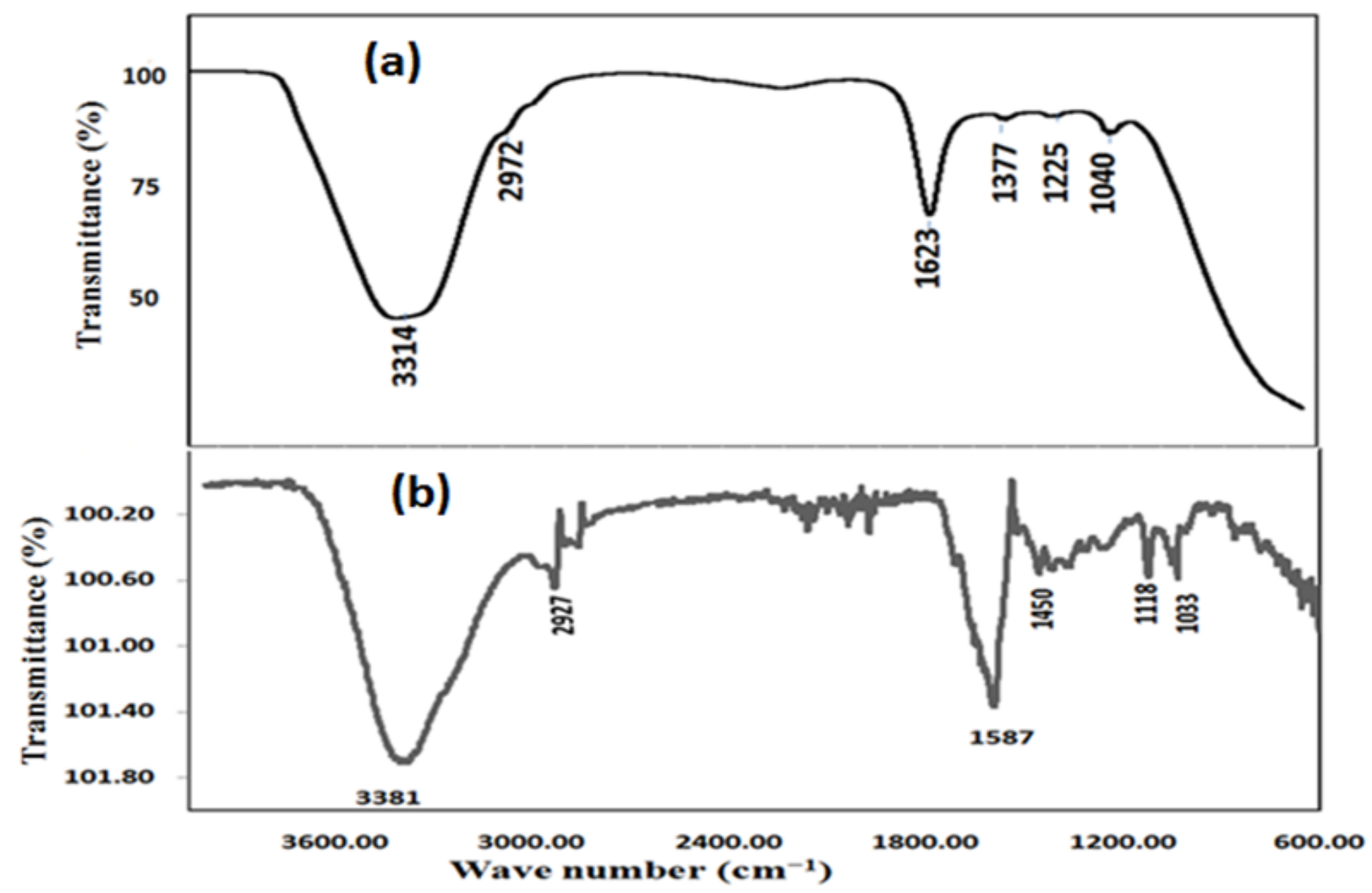

Figure 2

FTIR spectra of (a) Leaves extract of Launaea procumbens (b) Synthesized silver nanoparticles 

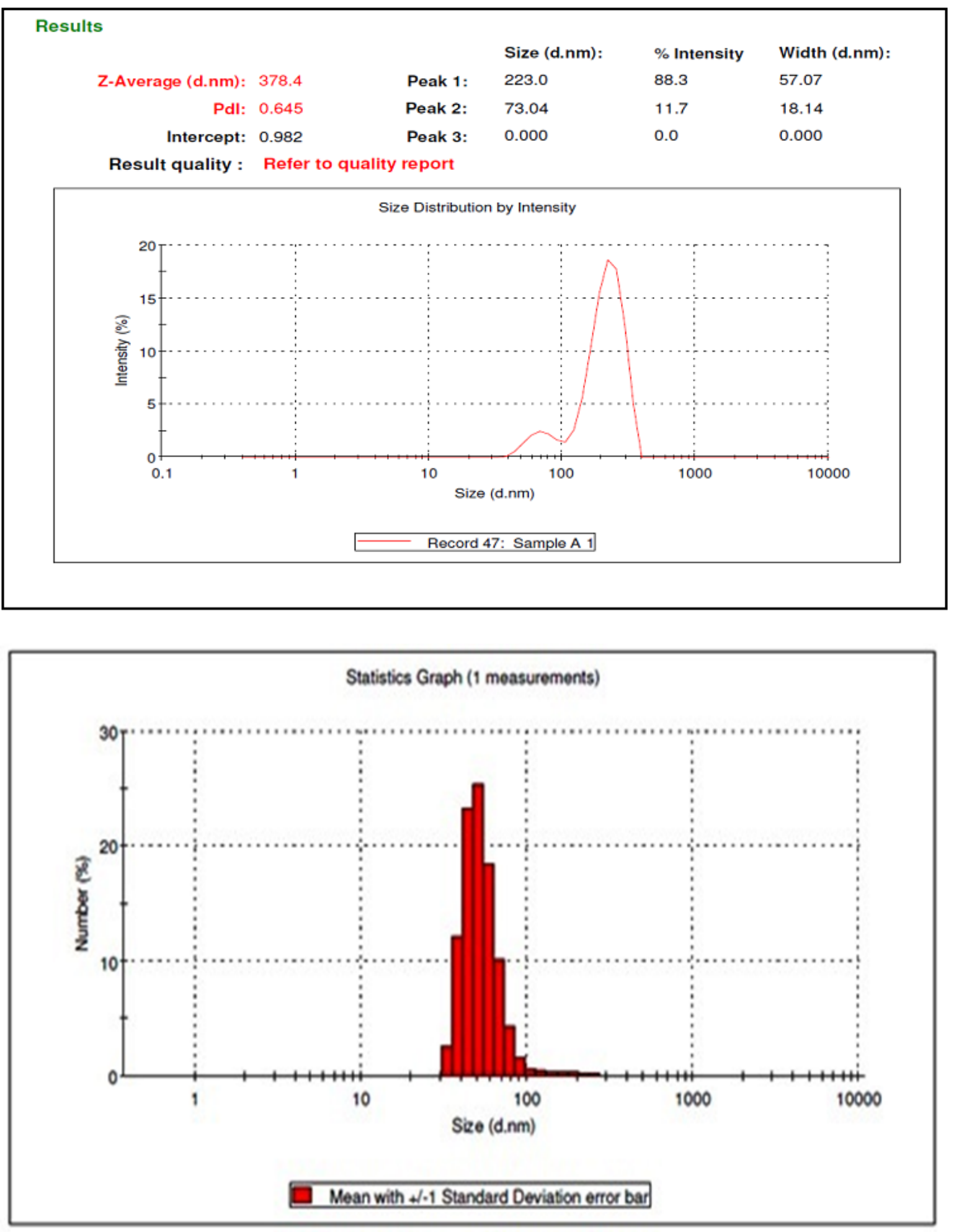

\section{Figure 3}

Particle size distribution of Silver Nanoparticles synthesized by Launaea procumbens extract. 

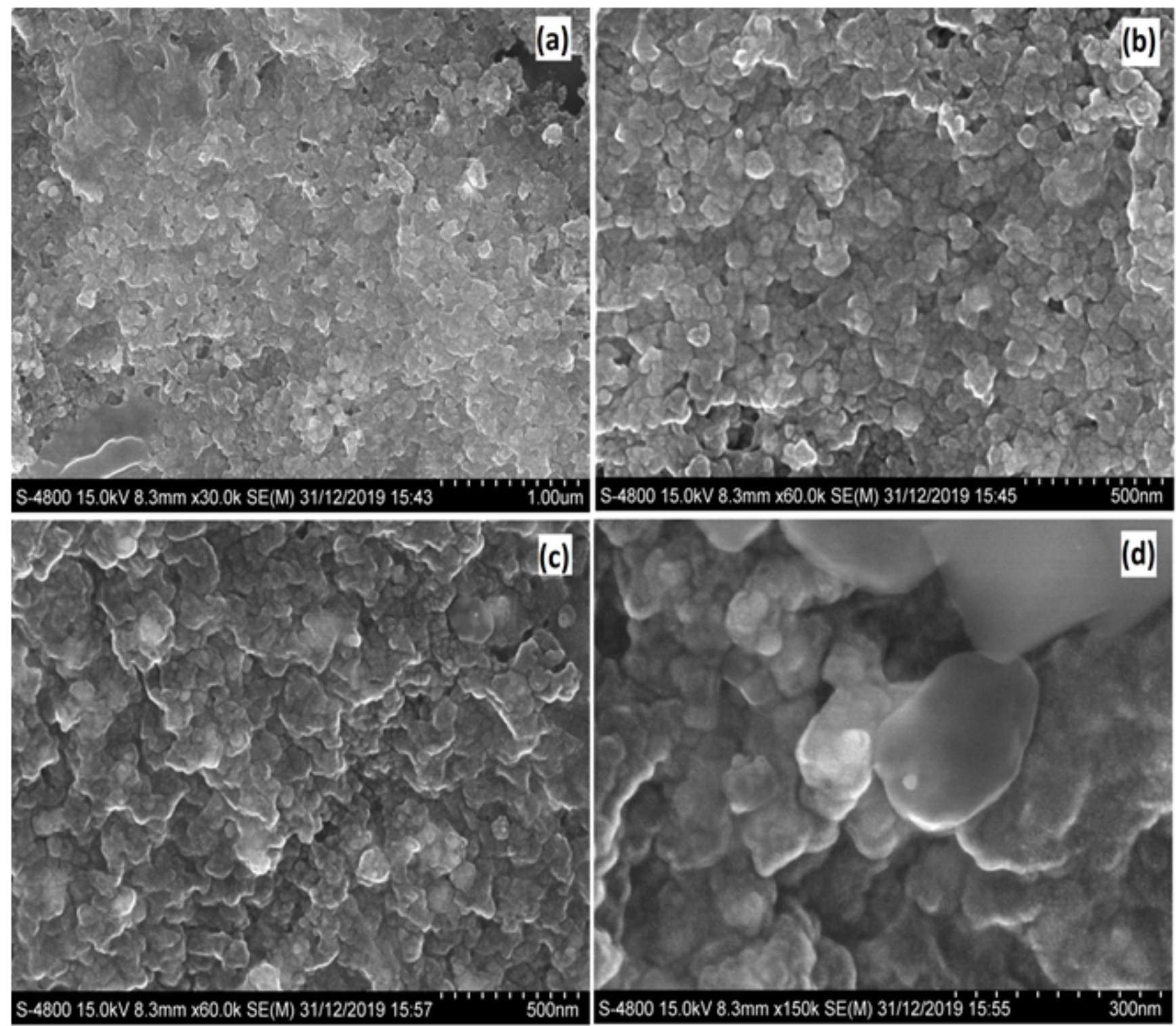

Figure 4

FE-SEM images of synthesized silver nanoparticles by Launaea procumbens leaves extract. 


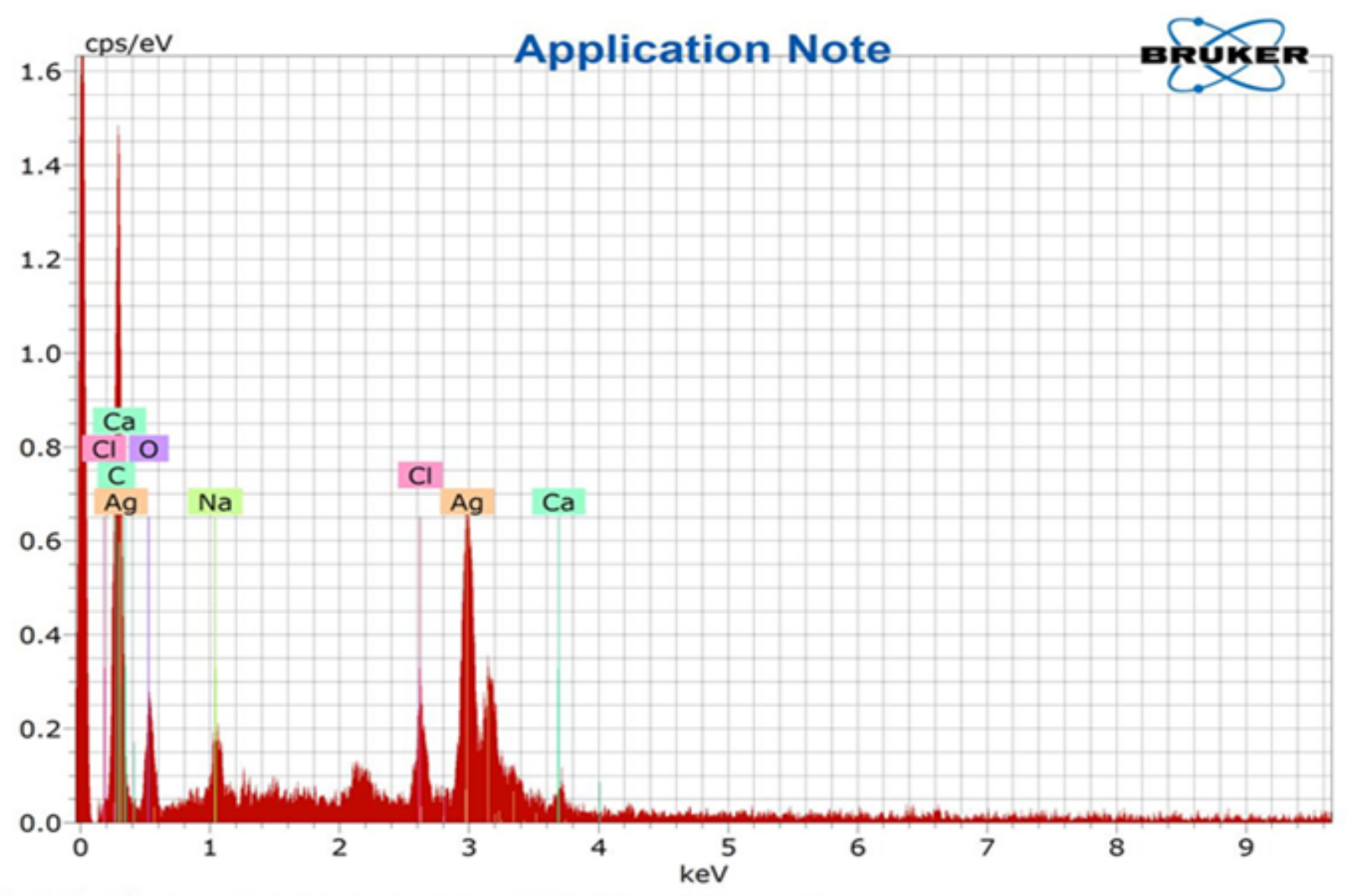

Figure 5

EDAX spectrum of synthesised AgNPs using Launaea procumbens leaves extract. 

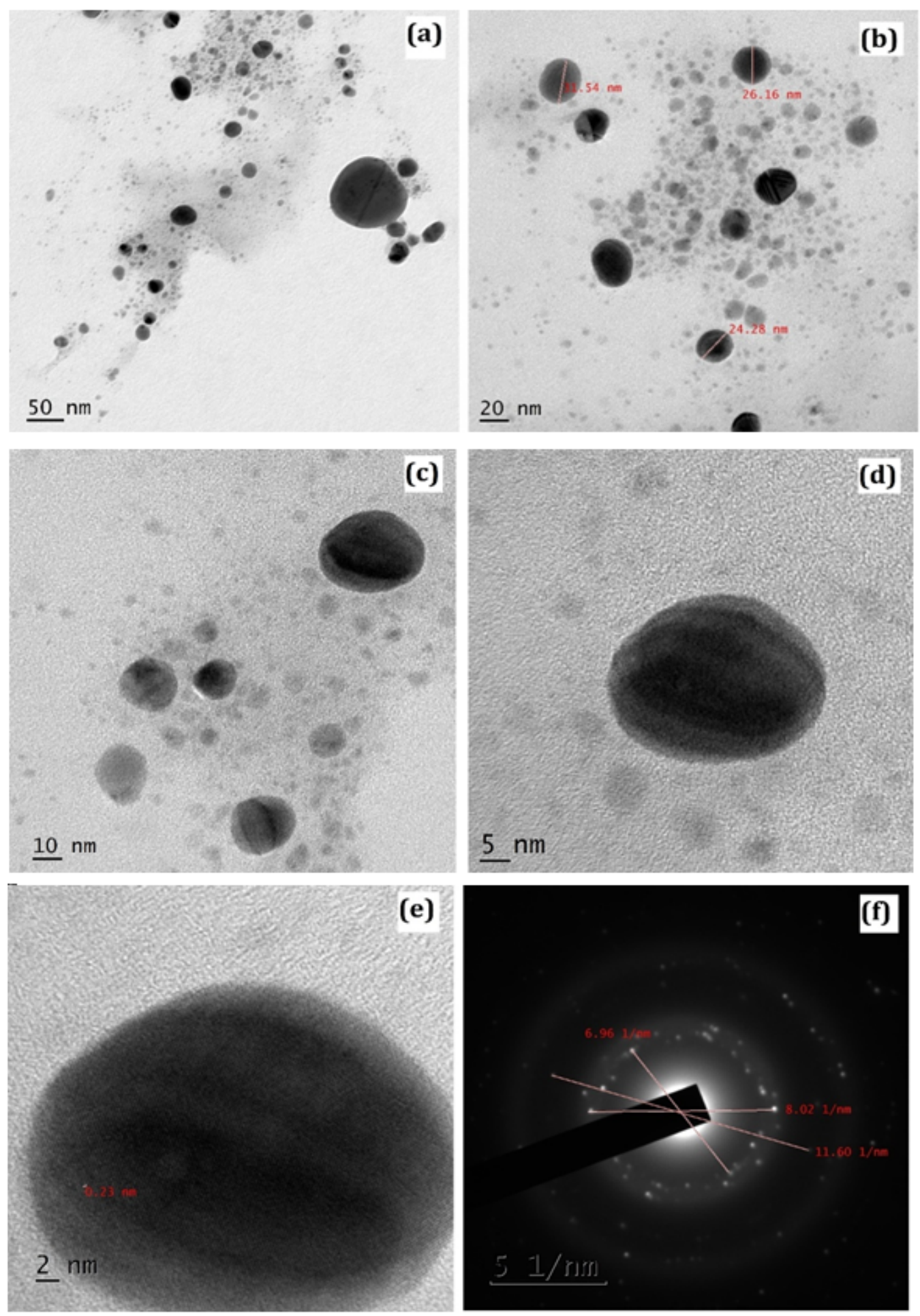

\section{Figure 6}

HR-TEM micrograph of silver nanoparticles (AgNPs) taken at different magnifications ranging from (a) $50 \mathrm{~nm}$, (b) $20 \mathrm{~nm}$, (c) $10 \mathrm{~nm}$ and (d) $5 \mathrm{~nm}$, (e) HR-TEM images of silver nanoparticles showing the lattice spacing of $0.23 \mathrm{~nm}$ and (f) SAED pattern show of silver nanoparticles. 

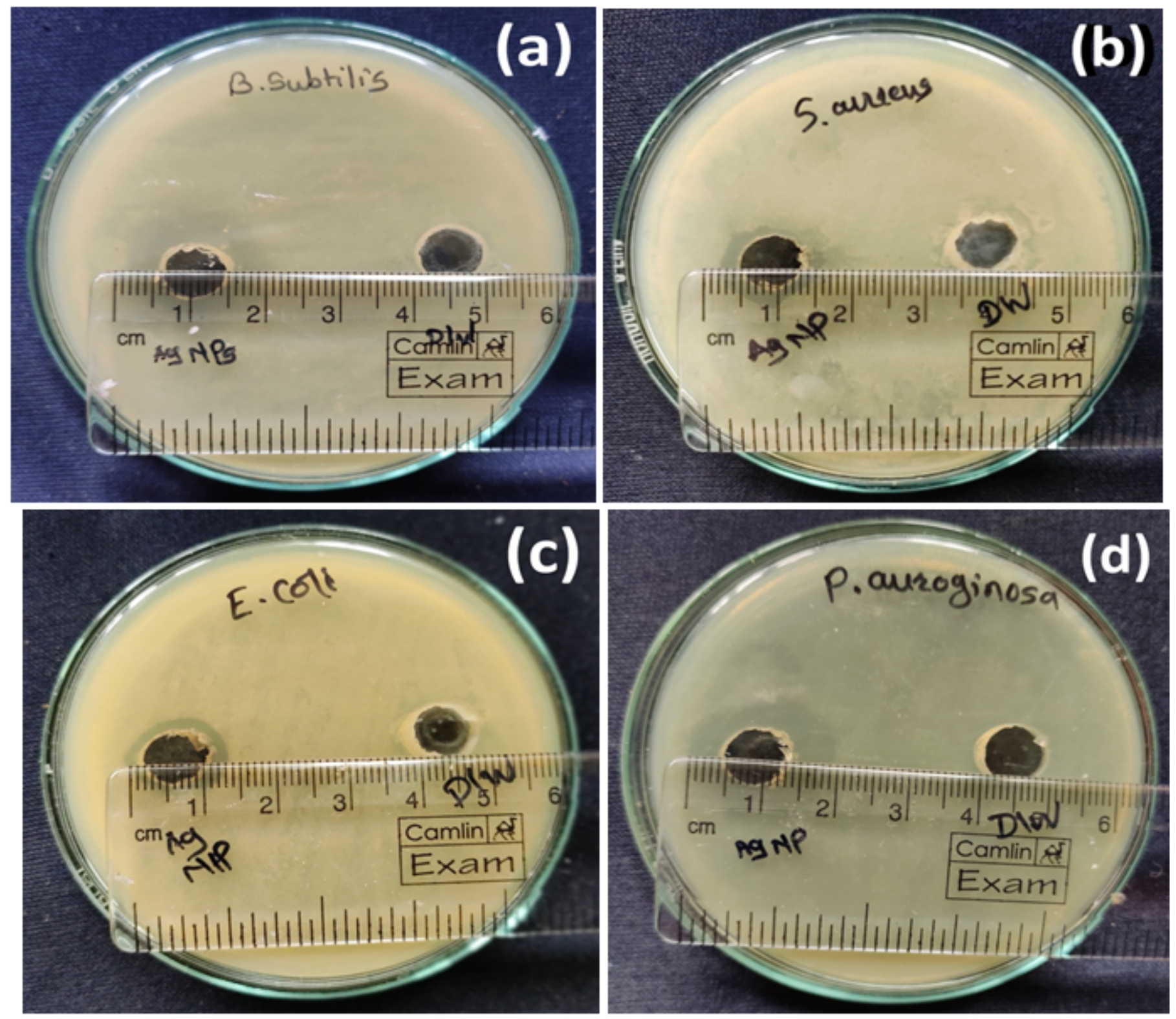

Figure 7

Antibacterial activity of silver nanoparticles against various bacterial strains Gram-positive bacteria (a) Bacillus subtilis (b) Staphylococcus aureus and Gram-negative bacteria (c) Escherichia coli and (d) Pseudomonas aeruginosa. 